\title{
Arthrospira (Spirulina) in tannery wastewaters Part 1: The microbial ecology of tannery waste stabilisation ponds and the management of noxious odour emissions using microalgal capping
}

\author{
Kevin Dunn and Peter Rose* \\ Department of Biochemistry, Microbiology and Biotechnology, Rhodes University, Grahamstown, South Africa
}

\begin{abstract}
We investigated the problem of noxious gas and odour emissions in zero-discharge evaporative tannery waste stabilisation ponds. These have been little-studied systems although they present one of few options for the management of tannery wastewaters in highly water-stressed areas. A three-year study of the microbial ecology of an evaporative waste stabilisation ponding cascade was undertaken and a descriptive account of the biology and the physico-chemical parameters related to odiferous gas release is reported. Large populations of Arthrospira (Spirulina) dominated the latter facultative ponds in the cascade where odour emission was substantially reduced compared to initial anaerobic ponds. Photosynthetic productivity maxima of up to $9000 \mathrm{mg} \cdot \mathrm{m}^{-2} \cdot \mathrm{day}^{-1}$ carbon fixation were measured in bloom conditions. Arthrospira production was associated with an oxygenated, alkaline layer established on the surface of facultative ponds ( $0.35 \mathrm{~m}$ in depth) in which oxidation of sulphide and ammonia, and the trapping of other odour-causing compounds was observed. An attempt was made to achieve comparable odour control in the anaerobic ponds by capping with recirculated microalgae-enriched effluent from facultative ponds. While this was shown to be effective in establishing an Arthrospira-dominant surface layer and an associated control of odour emissions in anaerobic ponds, large recirculation volumes (2:1) were required to maintain the Arthrospira population. Elevated salinity of recirculated facultative pond waters also negatively impacted the evaporative function in the low-salinity initial ponds in the cascade. An alternative method of Arthrospira capping was investigated which involved the construction of a free-standing high rate pond alongside the waste stabilisation pond system, and using a controlled feed of raw tannery effluent for optimising the cultivation of Arthrospira biomass. High biomass productivity was achieved in this unit $\left(12.87 \mathrm{~g} \cdot \mathrm{m}^{-2} \cdot \mathrm{day}^{-1}\right)$, using a low feed to effluent loading volume ratio (0.21:1) and subsequent capping of anaerobic ponds from this source achieved odour control comparable to facultative ponds. This study has shown that management of the odour problem in waste stabilisation ponds is possible and that leather production using the zerodischarge evaporative disposal operation may be compatible with a level of both environmental and social acceptability of these systems. Odour problems, alone, should thus not constrain tanning as one of the few industrial agricultural activities available in rural economies.
\end{abstract}

Keywords: tannery, wastewater, waste stabilisation ponds, odour, noxious gas, Spirulina, Arthrospira, microalgal biomass

\section{INTRODUCTION}

The rising costs of energy, both environmental and financial, have refocused interest in waste stabilisation ponds (WSP) as low-cost and effective means of wastewater treatment. The technology has been the subject of extensive review (Mara and Marecos Do Monte, 1987; De Pauw and Salamoni, 1991; Mara et al., 1996; Racault and Boutin, 2005; Munoz and Guieysse, 2006; von Sperling, 2007). Salinization of global water resources is an increasing problem (Lefebvre and Moletta, 2006), and evaporative disposal in zero-discharge WSP is one of few options for the environmentally effective management of tannery wastewaters in severely water-stressed areas, and where discharge to the public water system cannot be entertained. Despite the strategic significance of the technology in this application, few studies on conventional tannery WSP are reported in the literature (Shuttleworth, 1978; Rowswell et al., 1984), although high rate ponding (HRP) in this application has been evaluated at the experimental level (Rose et al., 1996;

\footnotetext{
To whom all correspondence should be addressed.

용 +27 82 801-1353; e-mail: p.rose@ru.ac.za

Received 29 May 2012; accepted in revised form 27 March 2013.
}

Dunn 1998; Rose et al. 2002; Tadesse et al., 2003).

Malfunction in WSP, however, does occur as they age (Lawty et al., 1995), with overloading and the accumulation of slowly biodegradable organics and dissolved solids manifesting, at times, in severe odour problems. In the case of tannery WSP, the social impacts of odour nuisance may be exacerbated by the release of noxious gases, including hydrogen sulphide and ammonia.

This report describes a 3-year study of a tannery WSP, in which linkages between the microbial ecology of the system, the formation of noxious odour-causing gases and possible manipulation of the biological processes may offer a conceptual basis for the more effective management of these systems.

\section{EXPERIMENTAL}

\section{Study site}

The WSP study site was a 13.6 ha cascade of 15 ponds with a total capacity of $197000 \mathrm{~m}^{3}$ and average depth of around $1 \mathrm{~m}$ (Fig. 1). Daily production averaged 1500 hides processed to wet blue leather with an average effluent load to the ponds of 460 $\mathrm{m}^{3} \cdot \mathrm{day}^{-1}$ and a surface organic loading rate of $107.3 \mathrm{~kg} \cdot \mathrm{ha}^{-1} \cdot \mathrm{day}^{-1}$ COD. Wastewaters were segregated at the tannery into alkaline 


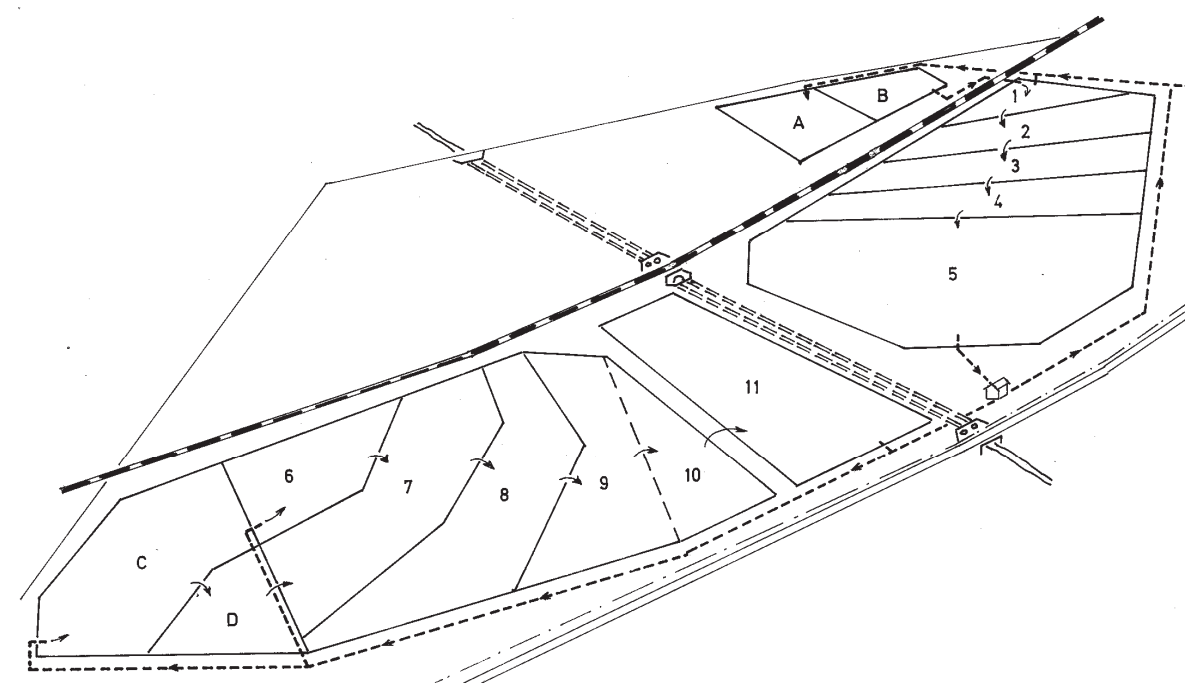

Figure 1

Plan drawing of the zerodischarge evaporative tannery waste stabilisation ponding system which served as the study site in this investigation. The effluent flow path led from Ponds $A$ and $B$, through Ponds 1 to 5 and via a sump pump from Ponds C to 11.

lime-sulphide and acidic tanning liquor streams and passed through pre-treatment including sulphide oxidation, blending and aeration followed by flocculant-assisted settling of a portion of the solids fraction, referred to hereafter as tannery effluent, and which provided the influent to the pond system. Table 1 shows the constituents of the effluent averaged over the 3-year study. Flow in the WSP passed from Ponds AB to Pond 5, which were functionally anaerobic. From a collection sump, effluent was pumped to Pond $\mathrm{C}$ and then flowed to Pond 11, which served as a sink for the final concentrate and also collection of stormwater runoff from the site. Ponds C to 11 functioned as facultative ponds. The tannery WSP was located at the town of Wellington, in the Western Province of South Africa, where the hot, dry summers of a Mediterranean climate provided a positive evaporation balance in the ponds. However, noxious gas releases from this system had caused corrosion damage to overhead railway electric cables and fencing, substantial die-back in adjacent vineyards, and social impacts, the severity of which caused the adjacent town to become known locally as 'Smellington' over the many decades the WSP had been in operation there.

\section{Sampling}

Pond sampling procedures followed Pearson et al. (1987). A subjective grab sampling protocol was used to draw surface samples from each pond across the WSP cascade from Ponds A to 11 (Fig. 1). The various samples drawn from a particular pond were combined and this was taken as representative of the conditions prevailing in that pond at the time of sampling. In addition, an objective sampling protocol was followed for the vertical sampling of strata in ponds using an ELE aquatic sampling apparatus. Here, a boat was used and samples were drawn at various depths from fixed points on a grid drawn on the pond site plan, regardless of upwelling, microalgal rafting and other circumstances prevailing in the ponds at the time of sampling. The samples drawn from a particular depth at various sampling sites in the same pond were pooled before analysis and were taken as representative of that stratum throughout the pond. Colour changes in the water body were measured objectively using the Forel-Ule Index numbering system (ELE).

Samples were drawn at 3 levels during each season over a 3-year period and the results reflect the average of these measurements for all ponds in the anaerobic and facultative

\begin{tabular}{|l|c|}
\hline \multicolumn{2}{|c|}{ TABLE 1 } \\
$\begin{array}{c}\text { Analysis of partly treated tannery effluent } \\
\text { fed to the zero-discharge waste stabilisation } \\
\text { ponding system. Monthly analysis values } \\
\text { averaged over the 3-year study. Standard } \\
\text { deviation in brackets. }\end{array}$ \\
\hline \multicolumn{2}{|c|}{$\left(\right.$ mg $\left.\ell^{-1}\right)$} \\
\hline Chemical oxygen demand & $3173(1810)$ \\
\hline Ammonia as $\mathrm{NH}_{3}$ & $731(98)$ \\
\hline Phosphate as $\mathrm{PO}_{4}$ & $19(12.5)$ \\
\hline Calcium & $226(11)$ \\
\hline Chloride & $4048(202)$ \\
\hline Sodium & $3090(198)$ \\
\hline Sulphate & $364(43)$ \\
\hline Sulphide & $1192(112)$ \\
\hline Total alkalinity $\left(\right.$ as $\left.\mathrm{CaCO}_{3}\right)$ & $525(49)$ \\
\hline Dissolved oxygen & $0.01(0.01)$ \\
\hline Salinity $\left(\mathrm{g} \cdot \ell^{-1}\right)$ & $10(0.039)$ \\
\hline pH & $8.2(0.2)$ \\
\hline
\end{tabular}

groups. Results for Ponds A, 5, 6 and 11 are reported as willustrative of the trends in the system.

\section{Tube growth studies}

The effect of photosynthetic oxygen production by Arthrospira on suppressing pigment formation in rhodobacterial cultures was evaluated in sealed tube studies. A mixed culture of Rhodobacteriacea was sourced from the tannery ponding system and grown in sealed tubes at $20^{\circ} \mathrm{C}$ under cool white fluorescent light $\left(1500 \mu \mathrm{mol} \cdot \mathrm{m}^{-2}\right)$ in fresh tannery effluent, also sourced from this site. Pigment formation following headspace injection of $\mathrm{N}_{2}$ and $\mathrm{O}_{2}$ in the culture tubes was compared with tubes inoculated with Arthrospira also sourced from the tannery ponds. In-situ growth in open pond conditions provided the control.

\section{Analysis}

Analytical procedures followed APHA Standard Methods (APHA, 2005). Measurements of photosynthetic productivity used the $\left[{ }^{14} \mathrm{C}\right]$-sodium bicarbonate $\mathrm{CO}_{2}$ fixation method modified by Oren (1992), using a Beckman LS3150T scintillation 
counter. Salinity was measured in an Atago salinity refractometer, and photosynthetically available radiation (PAR) was measured using a Skye Instruments 210 light sensor and SDL 2580 intelligent base unit. Provisional identification of Prokaryota was based on growth on Difco selective media (Malik, 1983) and Bergey's Manual of Systematic Bacteriology (Garrity et al., 2005). Eukaryotic algae and cyanobacteria (referred to collectively as microalgae here), were identified using type strains from the Culture Collection for Algae and Protozoa (CCAP). Cell counts were made in a Neubauer chamber using dark field microscopy. Chlorophyll $a$ was measured according to the method of Lichtenthaler (1987). Photosynthetic bacterial pigments were extracted into $100 \%$ acetone and absorbance measured in a Shimadzu spectrophotometer. Biogas was collected through a tube attached to an inverted cone located above the pond floor and gas analysed in a Chrompak gas chromatograph.

Attempts to correlate objective and subjective perceptions of odour using the Drager tube system proved unreliable, as was securing objective data on socially significant odour situations at low concentrations at points remote from the site. A more consistent result was achieved with subjective assessment by a sensory panel of 5 persons who rated odorous gas emissions on a scale of 1 to 5 ( 5 - seriously offensive; 4 - offensive; 3 - noticeable; 2 - present but not unpleasant; 1 - no odour noticeable). Results of panellists were combined and averaged.

\section{RESULTS AND DISCUSSION}

\section{Descriptive ecology of the tannery WSP}

The WSP cascade (Fig. 1) was characterised by clearly defined physico-chemical and biological gradients established horizontally across the system, with anaerobic conditions in the first part of the system (Ponds A to 5), and facultative operation in Ponds $\mathrm{C}$ to 11 . This transition was clearly distinguished by a striking change in colour from the brown (F-UI XVIII) effluent feed into the system, to a bright pink/purple (F-UI XXI) in the anaerobic ponds and to dark blue-green (F-UI XIII) in the facultative ponds. The colour change reflected the dominant forms of the microbial population in the two major parts of the system.

In anaerobic Ponds 1 to 5 purple photosynthetic bacteria, including the purple non-sulphur bacteria, Rhodobacterium spp. and Rhodospirillum spp., and purple sulphur bacteria, mainly Chromatium spp., were the dominant forms (average cell numbers $6.4 \times 10^{4} \cdot \mathrm{m}^{-1}$ ). This group was responsible for the pink/purple colour in these ponds. Small numbers of the green sulphur bacteria, mainly Chlorobium spp., also occurred. Dunaliella viridis was observed in small numbers in Pond 5 during the mid-summer period.

The microalgal population in facultative Ponds $\mathrm{C}$ to 11 was dominated by Arthrospira spp., the main forms of which were provisionally identified as morphotypes of Arthrospira platensis. Large near-mono species blooms of Arthrospira appeared in these ponds, mainly during summer. With autoflocculation of trichomes within the water column, cell aggregates rose to the surface and floated in large rafts of biomass. Photosynthetic productivity maxima of up to $9000 \mathrm{mg} \cdot \mathrm{m}^{-2} \cdot$ day $^{-1}$ carbon fixation were measured in these blooms which translates into a biomass yield of around $33 \mathrm{t} \cdot \mathrm{ha}^{-1} \cdot \mathrm{yr}^{-1}$ (dry mass). Populations of Dunaliella spp. also occurred with $D$. viridis giving way to $D$. salina as the salinity rose across the system. During evaporative concentration at the height of summer, populations of Halobacteriaceae were also observed in saline waters.

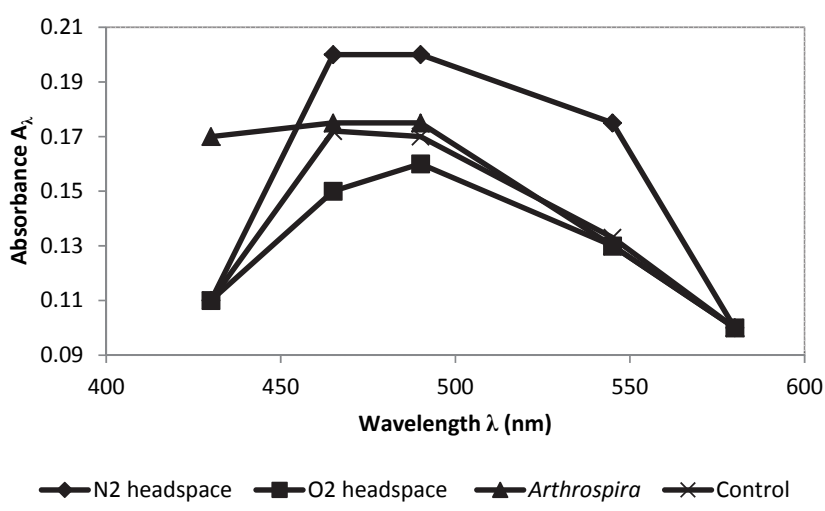

Figure 2

Pigment production (measured as absorbance change) in Rhodobacteriacea grown in sealed tubes with tannery effluent, and comparing anaerobic (nitrogen headspace) and aerobic (oxygen headspace) conditions with the effect on pigment production of photosynthetic oxygen production in the presence of Arthrospira platensis. The control reflects in-situ growth in open pond conditions.

The Rhodobacteriaceae appeared in the facultative ponds in similar numbers to those in the anaerobic ponds, but now mainly in a colourless form. The effect of oxygen in shifting Rhodobacterial metabolism to an un-pigmented, nonphotosynthetic growth form is shown in Fig. 2. Here, pigment formation during growth in anaerobic and aerobic sealed tube cultures was compared to growth in the presence of actively photosynthesising Arthrospira. A reduction in pigment formation of about $40 \%$ was observed for growth under oxygenated conditions whether caused by headspace injection or photosynthesis.

Figure 3 reports the physico-chemical and biological gradients that were observed to be established horizontally across the WSP for COD/salinity, chlorophyll a/C fixation/DO, total alkalinity/pH, ammonia/nitrate and sulphate/sulphide.

Figure $3 \mathrm{~A}$ shows the background of rising salinity across the evaporation cascade $\left(10 \mathrm{~g} \cdot \ell^{-1}\right.$ in the effluent to $60 \mathrm{~g} \cdot \ell^{-1}$ in Pond 11), against which the biological activity in the system took place, and the change in DO indicates the transition from anaerobic to facultative operation. The organic load in the tannery effluent was reduced by about $80 \%$ with flow through the anaerobic ponds to Pond 5. Methanogenic anaerobic digestion may have played a substantial part in this process with a $\mathrm{CH}_{4}: \mathrm{CO}_{2}$ ratio of 1:4 measured in gas sampled from collectors located above the bottom sludge layer in the anaerobic ponds. Heterotrophs, and a mixotrophic functionality among the photosynthetic bacteria, also participated in the degradation of intermediate organic compounds (Dunn, 1998).

The large photosynthetic productivity in the facultative ponds is shown by the steep rise in chlorophyll $a$ levels and carbon fixation rates, observed mainly from Pond 5 onwards (Fig. 3B). The rise in alkalinity and $\mathrm{pH}$ across the system correlates closely with the distribution of photosynthetic activity and accounts for the $2500 \mathrm{mg} \cdot \ell^{-1}$ total alkalinity that accumulates in the system by Pond 11 (Fig. 3C).

Breakdown of the high protein load in these effluents, and ammonification of the nitrogenous components, reflects in ammonia levels of over $900 \mathrm{mg} \cdot \ell^{-1}$ in the early stages of the pond system (Fig. 3D). While some nitrate is formed, a portion of which may be lost again by denitrification, the rapid decline in ammonia that occurs across the anaerobic ponds suggests stripping may account for a large fraction of nitrogen 

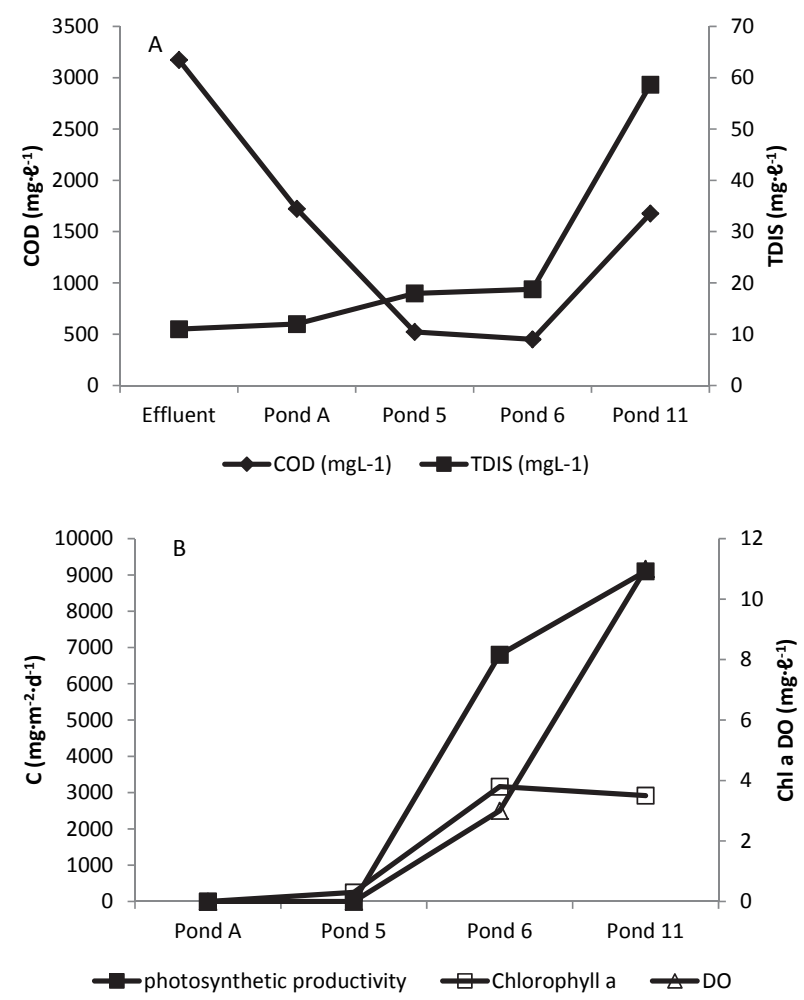

Figure 3

Horizontal profile of biological and physico-chemical gradients established across the waste stabilisation ponding cascade and comparing changes across the system for chemical oxygen demand, salinity, dissolved oxygen, chlorophyll a, photosynthetic productivity, total alkalinity, pH, ammonia, nitrate, sulphate and sulphide.

loss, particularly as the $\mathrm{pH}$ rises towards pKa 9.25 for ammonia (Lide, 2009). Reduced concentrations of ammonia, with a toxicity threshold to microalgal growth of around $100 \mathrm{mg} \cdot \ell^{-1}$, and depending importantly on $\mathrm{pH}$ (Abeliovitch, 1983), correlated quite closely with the point at which large-scale photosynthetic activity commences in these ponds. However, the uncoupling of photosynthesis by ammonia relates to the un-ionised $\mathrm{NH}_{3}$ form which increases as a percentage of total ammonia together with the rise in $\mathrm{pH}$ across the WSP system. This indicates the presence of a tight feedback loop in which micro-algal driven alkaline stripping needs to outperform the accumulation of unionised $\mathrm{NH}_{3}$ as a contribution to total $\mathrm{NH}_{3}$ levels in the water
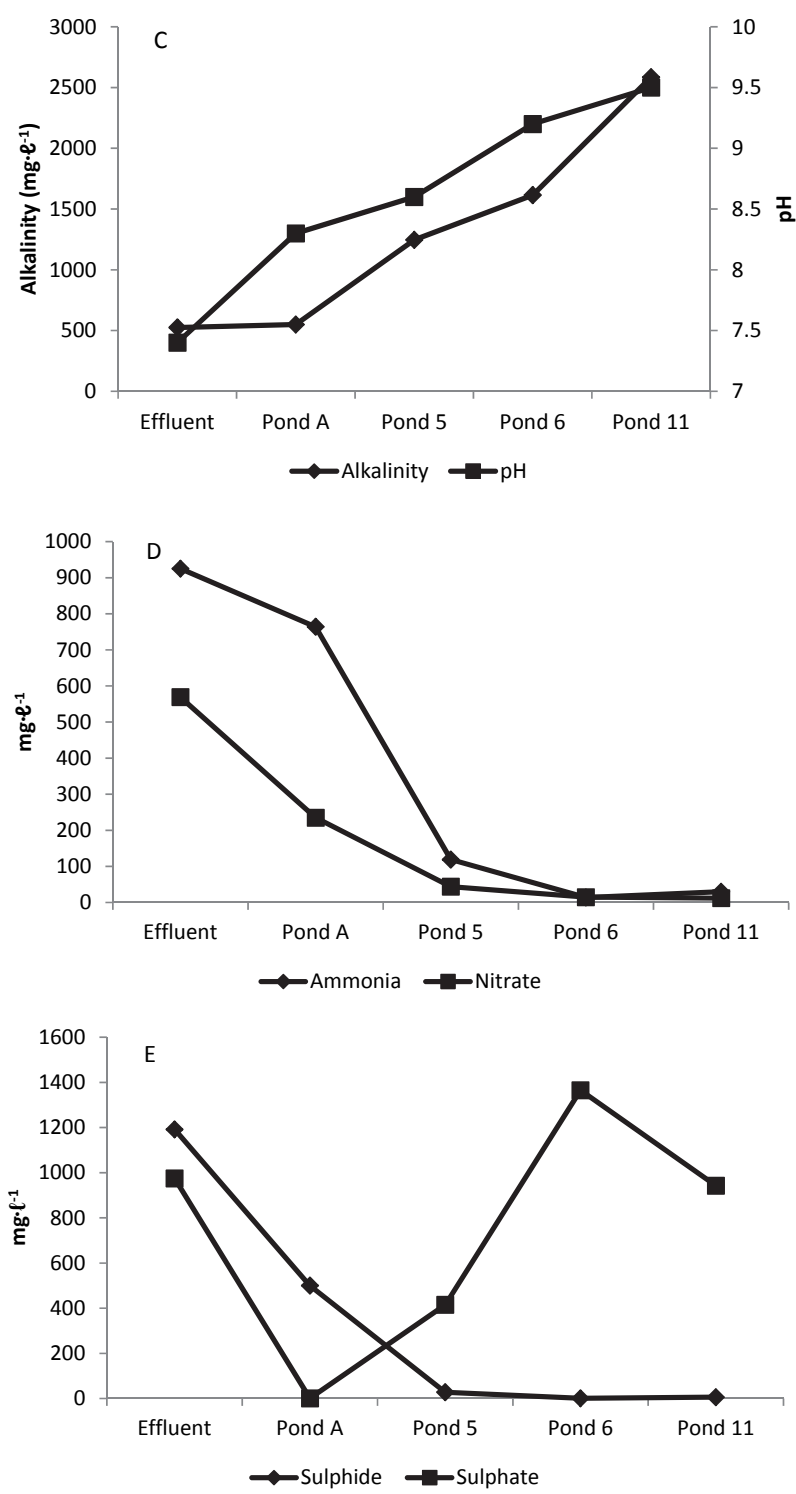

column. Table 2 shows that some nitrification of ammonia also occurs in the ponds and nitrate may not be seen to accumulate in the system to a greater extent due to denitrification and release as $\mathrm{N}_{2}$ gas with recycling of surface waters to the underlying anaerobic layers.

\begin{tabular}{|c|c|c|c|}
\hline \multicolumn{4}{|c|}{$\begin{array}{l}\text { TABLE } 2 \\
\text { Analysis of the water column in anaerobic ponds in the tannery waste } \\
\text { stabilisation ponding system. Samples were drawn at } 3 \text { levels during each } \\
\text { season over a 3-year period and the results reflect the average of these } \\
\text { measurements for all anaerobic ponds. Standard deviation in brackets. }\end{array}$} \\
\hline & Surface & $0.75 \mathrm{~m}$ & $1.5 \mathrm{~m}$ \\
\hline Temperature $\left({ }^{\circ} \mathrm{C}\right)$ & $22.1(7.9)$ & $19.8(5.1)$ & $19(4.8)$ \\
\hline Salinity $\left(\mathrm{g} \cdot \ell^{-1}\right)$ & $13.6(2.19)$ & $13.6(2)$ & $37.6(30.6)$ \\
\hline Light $\left(\mu\right.$ moles $\left.\cdot \mathrm{m}^{-2} \cdot \mathrm{sec}^{-1}\right)$ & $571(216)$ & $<1$ & $<1$ \\
\hline Chlorophyll $a\left(\mathrm{mg} \cdot \ell^{-1}\right)$ & $0.319(0.157)$ & $0.171(0.07)$ & $0.147(0.021)$ \\
\hline $\mathrm{pH}$ & 8.63 & 8.64 & 8.66 \\
\hline Sulphate $\left(\mathrm{mg} \cdot \ell^{-1}\right)$ & $759(182)$ & $585(151)$ & $302(73)$ \\
\hline Sulphide $\left(\mathrm{mg} \cdot \ell^{-1}\right)$ & $20(10)$ & $189(42)$ & $465(123)$ \\
\hline Ammonia $\left(\mathrm{mg} \cdot \ell^{-1}\right)$ & $54(26)$ & $61(30)$ & $65(27)$ \\
\hline Nitrate $\left(\mathrm{mg} \cdot \ell^{-1}\right)$ & 44 & 41 & 35 \\
\hline
\end{tabular}


The oxidation of sulphide present in the effluent occurred across the ponds. Figure 3E shows the removal of sulphide closely correlated with a rising sulphate concentration towards the latter ponds, which contributed to odour reduction. Oxidation of sulphide at the surface of the anaerobic ponds was observed with the formation, at times, of a white floating film of sulphur which would accumulate and, in windy conditions, be blown into thick paint-like windrows against the pond levees. Sulphur films have been described in other sulphidogenic environments and may play an important role in energy flux through these systems, as well as organic load removal, as sulphur is cycled repeatedly through its oxidised and reduced forms (Whitcomb et al., 1989; Molwantwa, 2007).

\section{Anaerobic ponds}

Vertical profiling of the water column in individual ponds was also investigated and Table 2 shows that defined gradients were established in anaerobic ponds and that the water column was stratified with respect to salinity and to a lesser extent temperature $\left(3^{\circ} \mathrm{C}\right.$ variance). Photosynthetically available light was virtually extinguished in the first $100 \mathrm{~mm}$ from the surface and, although low, chlorophyll $a$ levels show a comparable decline with depth. The $\mathrm{pH}$ remained constant at around $\mathrm{pH} 8.6$ at all stations in the water column (Table 2). Inverse relationships between sulphide and sulphate and between ammonia and nitrate indicate that both sulphur and nitrogen cycles were active between oxygen diffusion at the water surface and the rigorously anaerobic lower zones. While oxygen diffusion at the water surface clearly occurred, the oxygenated layer was so thin that it could not be measured with a conventional DO probe. Microprobe studies have shown this to be about $50 \mu \mathrm{m}$ in the presence of sulphur biofilm formation (Molwantwa, 2007).

\section{Facultative ponds}

In contrast to the anaerobic ponds, a substantial oxygenated layer of up to $0.35 \mathrm{~m}$ was established on the surface of facultative ponds with DO rising to $20 \mathrm{mg} \cdot \ell^{-1}$ by mid-afternoon during the summer period (Fig. 4A). Oxygen concentration in this zone remained close to saturation levels, even by early morning, during the winter period in these ponds. This profile correlates closely with chlorophyll $a$ levels, and with light extinction, in the water column; chlorophyll $a$ and light extinction are also reported for time of day and season in Figs. 4B and C.

Pronounced temperature stratification in the facultative ponds was observed with a flux of up to $8^{\circ} \mathrm{C}$ over the day in summer and $3^{\circ} \mathrm{C}$ during winter (Fig. 4D). The increase in temperature of around $5^{\circ} \mathrm{C}$ in summer, compared to anaerobic ponds, may be associated with increased light absorbance by the dark green colour and the metabolic activity of the Arthrospira blooms. Microalgal photosynthesis may convert light to heat energy at an efficiency approaching $90 \%$ Oswald (1988). Figure 5 compares average daily photosynthetic productivity in the water column for summer and winter conditions over the 3 -year period of the study. The concentration of $75 \%$ of total carbon fixation in the upper $0.15 \mathrm{~m}$ of the water column in summer may relate to both temperature and light effects, but possibly also to shading of lower-lying zones.

While the levels of the sulphate/sulphide and ammonia/ nitrate components related to odour production were substantially lower in the facultative compared to anaerobic ponds, these also appeared in fairly well-stratified zones within the water column of the facultative ponds (Table 3 ).
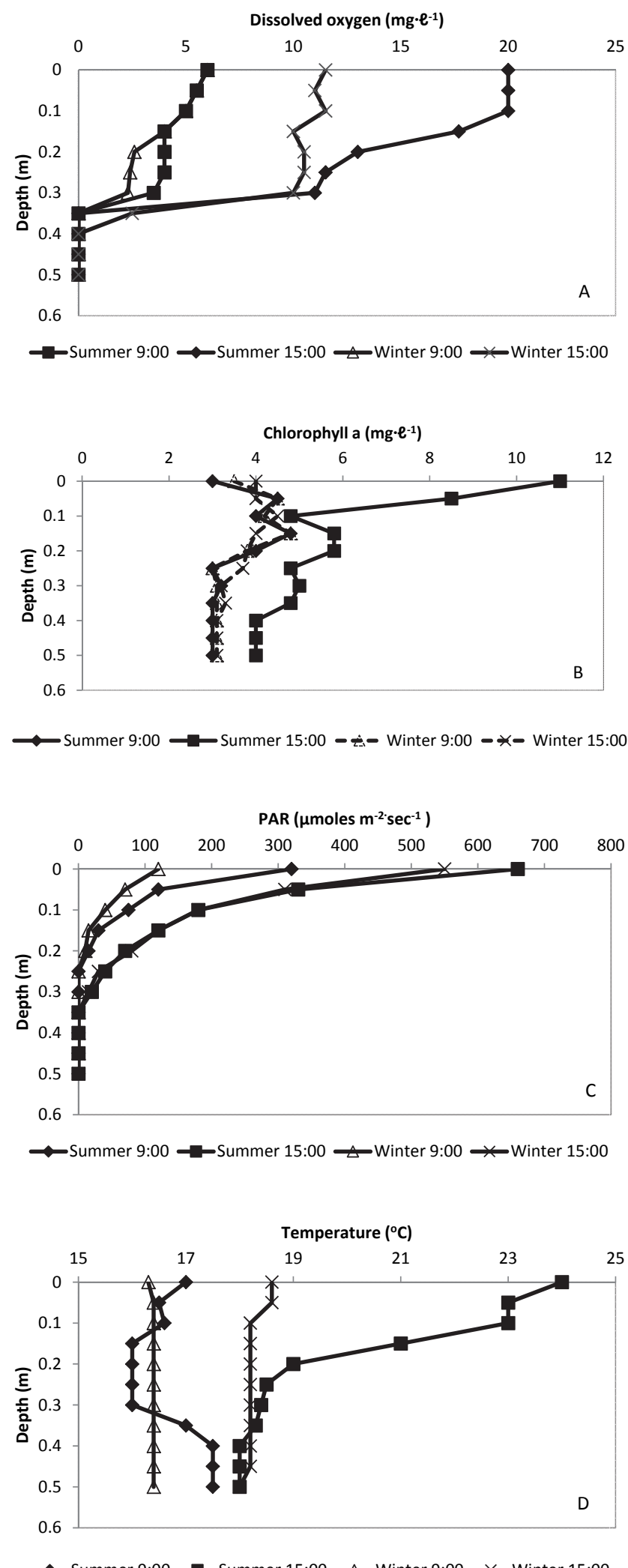

Figure 4

Vertical profile of the water column in the facultative ponds of the waste stabilisation ponding system recording dissolved oxygen (A), chlorophyll a (B), photosynthetically available radiation (C) and temperature (D), measured at 9:00 and 13:00 for winter and summer conditions. Results reflect an average of readings over a 3-year period. 


\begin{tabular}{|c|c|c|c|}
\hline \multicolumn{4}{|c|}{$\begin{array}{c}\text { TABLE } 3 \\
\text { Analysis of the water column in facultative Pond } 6 \\
\text { in the tannery waste stabilisation ponding system. } \\
\text { Samples were drawn at } 3 \text { levels during each season } \\
\text { over a 3-year period and the results averaged. } \\
\text { Standard deviation in brackets. }\end{array}$} \\
\hline & Surface & $0.75 \mathrm{~m}$ & $1.5 \mathrm{~m}$ \\
\hline Sulphate $\left(\mathrm{mg} \cdot \ell^{-1}\right)$ & $1066(547)$ & $923(402)$ & $832(348)$ \\
\hline Sulphide $\left(\mathrm{mg} \cdot \ell^{-1}\right)$ & $9(5)$ & $14(5)$ & $76(9)$ \\
\hline Ammonia $\left(\mathrm{mg} \cdot \ell^{-1}\right)$ & $22(1)$ & $25(2)$ & $30(4)$ \\
\hline Nitrate $\left(\mathrm{mg} \cdot \ell^{-1}\right)$ & $15(4.6)$ & $14(2.3)$ & $19(14)$ \\
\hline
\end{tabular}

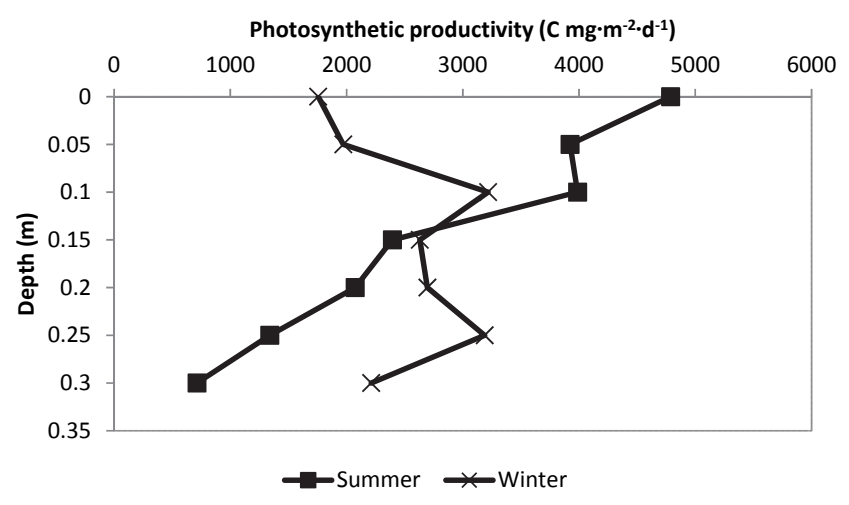

Figure 5

Vertical profile of average daily photosynthetic productivity in the water column in facultative ponds of the tannery waste stabilisation ponding system. Results reflect an average of readings over a 3-year period.

\section{Odour emission and control}

Odour emission in the WSP was evaluated by subjective sensory panel assessment over the 3-year study period and the results correlated closely with the anaerobic/facultative functionality of the ponds. Odour components were identified mainly as sulphidic, but ammonia, mercaptan and volatile fatty acid components were also noted by panellists. Anaerobic Ponds A to 5 were variably rated from seriously offensive (5) to offensive (4) and noticeable (3), while facultative Ponds C to 11 were consistently rated from not unpleasant (2) to no odour noticeable (1). During stormy north-westerly winds, which occurred mainly in winter, inversions in the anaerobic ponds gave rise to the substantially increased release of noxious gases (Ponds A to 5 all became 5+), and complaint incident reports from the local community, also a fairly reliable indicator of excessive gas release, escalated accordingly. Facultative ponds retained the 1-2 rating during these conditions.

Amelioration of odour release from the surface of WSP has been related to the presence of oxygenated, alkaline, warmer water on the surface of ponds. Chemical trapping of $\mathrm{H}_{2} \mathrm{~S}$, mercaptans and volatile fatty acids in alkaline waters has been suggested to be the underlying mechanism (De Pauw and Salamoni, 1991), and that the chemically-trapped components are then oxidised by bacteria in the euphotic zone (Almasi and Pescod, 1996). The solubility, and thus the trapping, of sulphide increases with increasing ionisation above pKa 7.05 (Lide, 2009).

Results reported in Tables 2 and 3 indicate an active biological sulphur cycle operating in the water column in both anaerobic and facultative ponds with the oxidation of sulphide to sulphate occurring in the oxygenated upper layers (Fig. 4a). Given this stratification profile in the WSP, it seems likely that both trapping and oxidation mechanisms were active in this system. On the other hand, ammonia stripping, another source of odour identified, is accelerated with rising $\mathrm{pH}$ (and ionisation reducing towards $\mathrm{pKa}$ 9.25). However, ammonia removal by nitrification in the upper oxygenated layer also occurred (Tables 1\&2).

Given the severity of the odour problem generated by the anaerobic ponds in this WSP system, and the associated social impacts, an attempt was made to duplicate the ameliorative function observed in the facultative ponds by establishing an Arthrospira population as a capping overlay on the surface of the anaerobic ponds. Initially this was attempted by the recirculation of micro-algal enriched Pond 11 water. The recirculation operation was sustained for several months but it was found that, due to poor growth in the anaerobic medium, transfer of high cell numbers was required to maintain the Arthrospira population on the surface of anaerobic ponds. Recirculation volumes of up to 2:1 were found to be required but could not be sustained in this system because the high salinity Pond 11 waters depressed evaporation rates in the initial ponds of the cascade.

However, during this recirculation operation, a substantial improvement in odour emission from the anaerobic ponds was noted and was consistently observed to be reduced from $5+$ to

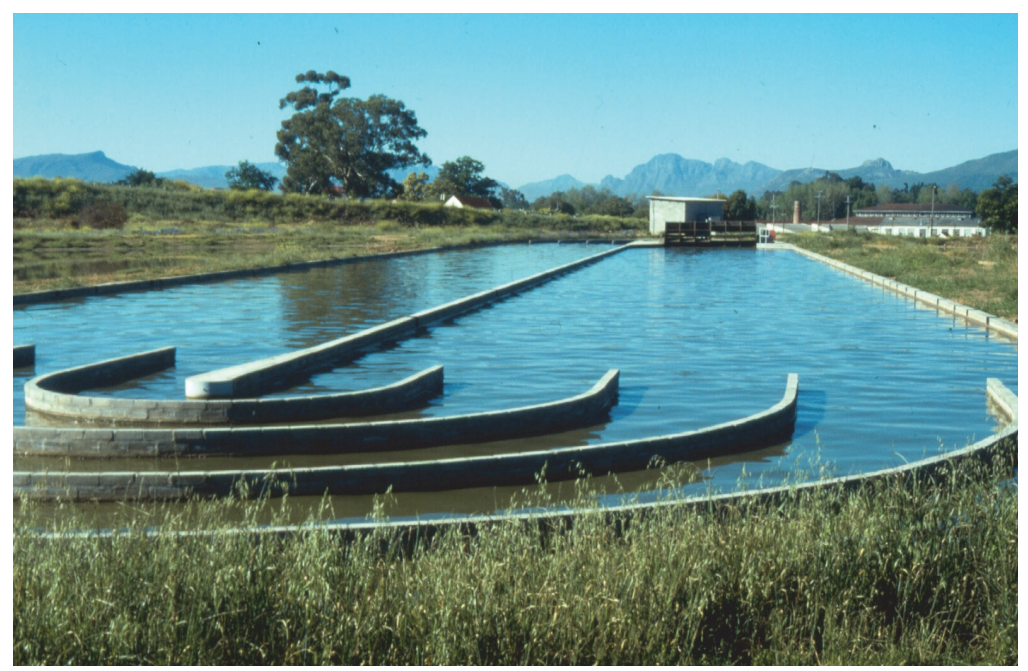

\section{Figure 6}

Photograph of the high-rate pond constructed alongside the tannery waste stabilisation ponding system investigated in this study. Arthrospiraenriched effluent was used to cap anaerobic ponds and this was shown to reduce odour emissions in these ponds. 
2-3 on sensory panel assessment. For these reasons, a followup project was undertaken involving the construction of a free-standing paddle-driven high rate pond (HRP), alongside the tannery WSP, in which Arthrospira growth and biomass production in tannery effluent could be managed under controlled conditions. Where successful, a high-density culture, in low salinity medium and in logarithmic growth phase, would then be available to be continuously seeded to the surface of the anaerobic ponds without relying on active growth in this unfavourable medium to maintain the biomass levels required to control noxious odour emissions from these ponds.

Studies underpinning the controlled use of tannery effluent as a growth medium for optimising Arthrospira production are detailed in Part 2 of this report (Dunn et al., 2013). The development, construction and operation of a $2500 \mathrm{~m}^{2}$ Arthrospira HRP at the tannery WSP site (Fig. 6), and the studies underpinning the engineering of this process have been described elsewhere (Rose and Dunn, 2013). With control of Arthrospira growth achieved in this way, an average biomass productivity of $12.87 \mathrm{~g} \cdot \mathrm{m}^{-2} \cdot \mathrm{day}^{-1}$ carbon fixation was established in the HRP.

HRP water was then used to overlay the surface of the anaerobic ponds in the WSP system and it was shown that an aerobic zone of around $0.20 \mathrm{~m}$ could be reliably established on the surface of these ponds at a surface loading rate of 16.1 $\mathrm{m}^{3} \cdot \mathrm{ha}^{-1} \cdot \mathrm{day}^{-1}$. This entailed an HRP feed to effluent loading ratio of 0.21:1.

The results of the HRP study indicated a direct correlation between Arthrospira capping of the anaerobic ponds and the reduction of odour status in sensory panel assessments from $5+$ to a rating between 1 and 3 during most weather conditions. This indicated sulphide, ammonia and mercaptans reduced to close to, or below, sensory threshold levels of $0.00047 \mathrm{ppm}$, $0.037 \mathrm{ppm}$ and $0.0011 \mathrm{ppm}$, respectively (Iowa State University Extension, 2004). However, during gale conditions inversions did occur and higher odour ratings were noted, but in this case were less severe. While complaints at these times reflected ongoing social concern, the overall assessment from the local community was that the intensity of the odour problem had reduced substantially compared to that which had previously prevailed.

\section{CONCLUSIONS}

An investigation of the microbial ecology and physico-chemical parameters in a zero-discharge evaporative tannery WSP demonstrated the establishment of clearly-defined aerobic and underlying anaerobic functional compartments maintained by Arthrospira growth on the surface of facultative ponds in the system. This configuration was found to correlate closely with a reduction in odour emissions from these ponds.

It was shown that establishment of Arthrospira growth on the surface of anaerobic ponds could reduce odour emissions but that capping with high concentrations of Arthriospira cells from facultative ponds by recirculation could not be sustained due to the large volumes required and also the salinity transfers involved.

The location of a free-standing HRP alongside the WSP, and producing high concentrations of Arthrospira biomass under optimal growth conditions, provided low-volume capping of anaerobic ponds and was shown to be an effective strategy in odour control in these ponds;

While the presence of odour-producing anaerobic waters in tannery WSP will always be accompanied by noxious gas production within these systems, this study has shown that management of the problem is possible. Leather production using the zero-discharge evaporative WSP disposal operation may thus be compatible with a level of environmental and social acceptability, and odour problems, alone, should thus not constrain tanning as one of the few industrial agricultural beneficiation activities available in rural economies.

\section{ACKNOWLEDGEMENTS}

The authors wish to acknowledge the support of Rhodes University, Messrs. RE Newson and R Smith, formerly of Mossop-Western Leathers Co. Pty. Ltd., and the Water Research Commission for support grants and permission to use data from WRC Report No. TT 188/02 (Rose et al., 2002).

\section{REFERENCES}

ABELIOVICH A (1983) The effects of unbalanced ammonia and BOD concentrations on oxidation ponds. Water Res. 17 299-301.

ALMASI A and PESCOD MB (1996) Wastewater treatment mechanisms in anoxic stabilisation ponds. Water Sci. Technol. 33 125-32.

APHA (2005) Standard Methods for the Examination of Water and Wastewater (21 $1^{\text {st }}$ edn.). APHA, Washington.

DE PAUW N and SALOMONI C (1991) The use of microalgae in wastewater treatment: achievements and constraints. In: Madoni P (ed.) Biological Approach to Sewage Treatment Process: Current Status and Perspectives. Centro Luigi Bazzucchi, Perugia. 329-352.

DUNN KM (1998) The biotechnology of high rate algal ponding systems in the treatment of saline tannery wastewaters. $\mathrm{PhD}$ thesis, Rhodes University, Grahamstown, South Africa.

DUNN KM, MAART B and ROSE PD (2013) Arthrospira (Spirulina) in tannery wastewaters. Part 2: Evaluation of tannery wastewater as production media for the mass culture of Arthrospira biomass. Water SA 39 (2) 279-284.

GARRITY GM, BRENNER DJ and FRIEG NR (2005). Bergey's Manual of Systematic Bacteriology. Springer, Berlin.

IOWA STATE UNIVERSITY EXTENSION (2004) The Science of Smell Part 1: Odor perception and physiological response. URL: http:// www.extension.iastate.edu/airquality (Accessed 22 May 2012).

LAWTY R, DE B ASHWORTHY D and MARA DD (1995) Waste stabilisation pond decommissioning: a painful but necessary decision. Water Sci. Technol. 31 1-8.

LEFEBVRE $O$ and MOLETTA R (2006) Treatment of organic pollution in industrial saline wastewater: A literature review. Water Res. 40 (20) 3671-3682.

LICHTENTHALER HK (1987) Chlorophylls and carotenoids: Pigments of photosynthetic biomembranes. Methods Enzymol. 148 $350-371$.

LIDE DR (2009) (ed.) CRC Handbook of Chemistry and Physics $\left(90^{\text {th }}\right.$ edn.) CRC Press, Boca Raton.

MALIK KA (1983) A modified method for the cultivation of phototrophic bacteria. J. Microbiol. Methods 1342-352.

MARA DD and MARECOS DO MONTE MH (1987) Waste stabilization ponds. Water Sci. Technol. 19 1-401.

MARA DD, PEARSON HW and SILVA SA (1996) Waste stabilisation ponds: technology and applications. Water Sci. Technol. 33 1-262.

MOLWANTWA JB (2007) Floating sulphur biofilms: structure, function and biotechnology. PhD thesis, Rhodes University, Grahamstown, South Africa.

MUNOZ R and GUIEYSSE B (2006) Algal bacterial processes for the treatment of hazardous contaminants: a review. Water Res. 40 (15) 2799-2815.

OREN A (1992) Bacterial activities in the Dead Sea, 1980-1991: survival at the upper limit of salinity. Int. J. Salt Lake Res. 1 7-20.

OSWALD WJ (1988) Large-scale algal systems (engineering aspects). In: Borowitzka MA and Borowitzka LJ (eds.) Micro-Algal Biotechnology. Cambridge University Press, Cambridge UK.

PEARSON HW, MARA DD and BARTONE CR (1987) Guidelines for minimum evaluation of performance of full-scale waste stabilisation pond systems. Water Sci. Technol. 21 1067-1075. 
RACAULT Y and BOUTIN C (2005) Waste stabilisation ponds in France: state of the art and recent trends. Water Sci. Technol. 12 $1-9$.

ROSE PD, MAART BA, DUNN KM, ROWSWELL RA and BRITS P (1996) High rate algal oxidation ponding for the treatment of tannery effluents. Water Sci. Technol. 33 219-227.

ROSE PD, DUNN KM, MAART BA and SHIPIN O (2002) Integrated Algal Ponding Systems and the Treatment of Saline Wastewaters. Part 1 - Meso-saline Wastewaters: The Spirulina Model. WRC Report No. TT 188/02. Water Research Commission, Pretoria.

ROSE PD and DUNN KM (2013) A high rate ponding unit operation linking treatment of tannery effluent and Arthrospira (Spirulina) biomass production. 1: Process development. Biomass Bioenerg. 51 $183-188$.
ROWSWELL RA, COOPER DA and SHUTTLEWORTH SG (1984) Evaporation ponds: A solution for tannery effluent disposal. J. Soc. Leather Technol. Chem. 69 123-129.

SHUTTLEWORTH SG (1978) The evaluation of tannery effluent treatment - guidelines for further investigations. J. Soc. Leather Technol. Chem. 6287.

TADESSE I, GREENE FB and PUHAKKA J (2003) The role of sulphidogenesis in anaerobic treatment phase of tannery wastewater treatment in advanced integrated wastewater pond system. Biodegradation 14 219-227.

VON SPERLING M (2007) Waste Stabilisation Ponds. IWA Publishing, London, UK.

WHITCOMB JH, DELAUNE RD and PATRICK JR (1989) Chemical oxidation of sulfide to elemental sulphur: its possible role in marsh energy flow. Mar. Chem. 26 205-214. 